\title{
Effect of year, sampling month and grape cultivar on noble rot incidence, mycelial growth rate and morphological type of Botrytis cinerea during noble rot development
}

\author{
Júlia Hegyi-Kaló • Imre J. Holb • Szabina Lengyel • \\ Ákos Juhász • Kálmán Zoltán Váczy
}

Accepted: 10 April 2019/Published online: 30 April 2019

(C) The Author(s) 2019

\begin{abstract}
The aims of this three-year study were firstly to investigate the effect of 3 years, three sampling months and two grape cultivars (cvs) on noble rot incidence in the field and on the mycelial growth rate of Botrytis cinerea isolates in vitro under three incubation temperatures, and secondly to show possible effects of years, sampling months and cultivars on eight morphological (four mycelial: M I-IV and four sclerotial: S I-IV) types of $B$. cinerea isolates incubated at $20{ }^{\circ} \mathrm{C}$. In addition, the relationship between monthly noble rot incidences and morphological types was calculated. Analyses of variance indicated significant differences
\end{abstract}

Júlia Hegyi-Kaló and Imre J. Holb contributed equally to this work.

J. Hegyi-Kaló · S. Lengyel · Á. Juhász · K. Z. Váczy

Food and Wine Research Institute, Eszterházy Károly University, 6 Leányka street, Eger H-3300, Hungary

\section{J. Hegyi-Kaló · Á. Juhász}

Szent István University, 1 Páter Károly street, Gödöllő H-2100, Hungary

\section{J. Holb $(\bowtie)$}

Institute of Horticulture, University of Debrecen, 138

Böszörményi street, Debrecen H-4032, Hungary

e-mail: holbimre@gmail.com

\section{J. Holb}

Centre for Agricultural Research, Plant Protection Institute, Hungarian Academy of Sciences, P.O. Box 102, Budapest 1525, Hungary

\section{S. Lengyel}

Institute of Biotechnology and Drug Research,

Erwin-Schrödinger-Str. 56, D-67663 Kaiserslautern, Germany among years, months and cultivars for noble rot incidence. Noble rot incidences were significantly higher on cv. 'Turán' compared to cv. 'Olaszrizling' in November in all years. Noble rot incidences were significantly lower in September compared to values in November in all years. Analyses of variance indicated significant differences among years, months, and temperatures for mycelial growth rate but the differences among cultivars were non-significant. Mycelial growth rates at 15 and $25^{\circ} \mathrm{C}$ were higher in 2013 compared to 2014 and 2015 ; however, the rates at $20{ }^{\circ} \mathrm{C}$ were higher in 2014 compared to 2013 and 2015. The overall mean growth rate was the highest in 2013 (76 mm) compared to either 2014 or 2015 (65 or $69 \mathrm{~mm}$, respectively). Mycelial growth rates were significantly different between earlier (September) and later (November) sampling months in three cases: i) in 2013 at $15^{\circ} \mathrm{C}$, ii) in 2014 at $20^{\circ} \mathrm{C}$, and iii) in 2015 at $25{ }^{\circ} \mathrm{C}$. Analyses of variance indicated significant differences among years and months for the frequency distribution of the morphological types but the differences among cultivars were non-significant. In general, the most frequent mycelial and sclerotial types were M I-III and S IV (means were 21.5, 16.1, 28.9, and $13.1 \%$, respectively). Isolates of mycelial types were more frequent in 2013 ( $\sum$ M-type $82.2 \%$ ) compared to 2015 ( $\sum$ M-type $57.1 \%$ ). The frequency distributions of morphological types among sampling months showed differences between the earlier (September or/and October) and the later months (November) in 2013 for M IIII, S II and S IV types; in 2014 for M I, M III, M IV, S I, S III and S IV types; and in 2015 for M I, M IV and S IIV types. Pearson correlation analyses revealed a 
significant positive relationship between morphological types ( $\sum$ S-type and $\sum \mathrm{M}$-type) and monthly noble rot incidences ( $r=0.676$ and $P=0.048$ ). In summary, our results showed possible effects of year/sampling month on noble rot incidence in connection with mycelial growth rate and morphological types of $B$. cinerea strains isolated during noble rot development.

Keywords Botrytis cinerea $\cdot$ Mycelial growth rate . Morphological type $\cdot$ Noble rot incidence $\cdot$ Year . Sampling month $\cdot$ Temperature

Botrytis cinerea is a common and widespread ascomycete fungus and necrotrophic pathogen attacking numerous different plant species e.g. grape, tomato, kiwi fruit, strawberry and raspberry, herbaceous, shrub and tree species (Holtz et al. 2007). In grape, the pathogen can cause gray mold resulting rot of berries but under certain microclimatic conditions, infected berries go through the process of noble rot (Magyar 2011; Fournier et al. 2013).

Botrytis cinerea populations were widely studied in European wine regions suggesting that several factors can influence the population structure such as host, geographic origin, mode of reproduction, occurrence of mutations, the presence of transposon elements, and/or gene-flow (Campia et al. 2016). Geographical diversity among the pathogen populations was associated with gray mold versus noble rot symptoms in various wine regions of France (Fournier et al. 2013; Walker et al. 2015). Authors showed that noble rot development occurred under the combinatory effects of climate, cultivar, year, cultural practices, and berry microbiome (Ribéreau-Gayon et al. 2006; Blanco-Ulate et al. 2015). The occurrence of noble rot is dependent mainly on microclimatic conditions (Ciliberti et al. 2015b; Elad et al. 2016); however, there is a lack of information that how the different microclimatic conditions are connected to B. cinerea phenotypes (Martinez et al. 2003; Martinez et al. 2005; Cantoral et al. 2011; Ciliberti et al. 2015a; Ciliberti et al. 2015b).

The critical period for noble rot is the autumn in Hungary (Magyar 2011). Botrytis cinerea is either actively penetrating the host by means of enzimes degrading the cellular wall or passively throught wounds and cracks into the berry skin. In addition, latent infection pathway could also play an essential role in noble rot development. Latent infection is usually developing from flowering to young cluster development, but remains quiescent (Williamson et al. 2007). Later, from veraison to ripening and harvest, become visible and colonize the grape bunch (González-Domínguez et al. 2015, 2019). This may serve as a source of inoculum inside the bunch or causes berry to berry infection by mycelium (Elad et al. 2016). The burgeon starts at end-August depending on the grape cultivar in Hungary and the harvest time of noble rot berries ranges between mid-September and end-November. Therefore, weather conditions (e.g. precipitation, humidity, mean temperature) during the autumn months play an essential role in the botrytisation process (Ribéreau-Gayon et al. 2006). In Tokaj wine region, favourable weather conditions for noble rot occur more frequently in the second half of the autumn; hence noble rot development is more successful on late ripening grape cultivars compared to the early ripening ones (Bene and Magyar 2004; Magyar and Bene 2006). This phenomenon may appear in different features of $B$. cinerea isolates during early or late the autumn depending on cultivar maturity. Most studies investigated $B$. cinerea isolates collected from various grape cultivars (Martinez et al. 2003; Martinez et al. 2005; Váczy et al. 2008; Ciliberti et al. 2015a; Ciliberti et al. 2015b) but isolate features were not investigated in relation to the early or late autumn period of noble rot development on various cultivars.

Mycelial growth rate, as one of the basic isolate features, was studied widely for noble rot caused by B. cinerea (Youssef and Roberto 2014). An intensive mycelial growth resulted in a higher infective capacity, and the lower infective capacity was connected to a less sclerotia production (Cantoral et al. 2011; Vallejo et al. 2003). A more wider phenotypic characterizations of $B$. cinerea strains during noble rot were performed for instance by describing the morphological types and features (e.g. Martinez et al. 2003; Lorenzini and Zapparoli 2014) or the effect of water activity on mycelial and conidial growth rates of the $B$. cinerea strains (Rousseau and Doneche 2001). However, the connections among the morphological types, sampling months or grape cultivars were not investigated on isolates originated from various periods of noble rot development.

The aims of this three-years study were: firstly, to investigate the effect of 3 years, three sampling months during noble rot development and two grape cultivars on noble rot incidence in the field and on the mycelial 
growth rate of $B$. cinerea isolates under three incubation temperatures; secondly, to show possible effects of years, sampling months and cultivars on eight morphological (four mycelial and four sclerotial) types of B. cinerea isolates incubated at $20^{\circ} \mathrm{C}$; and thirdly, to calculate the overall relationship between monthly noble rot incidences and morphological types.

The study was performed in three consecutive years (2013-2015) in a vineyard located at Somolya (47 54' $00^{\prime \prime} \mathrm{N}$; $20^{\circ} 30^{\prime} 00^{\prime}$ E) in the Eger wine region, EasternHungary. The main soil type was brownish forest soil with riolit tufa stones. The vineyard was planted in 1998 with planting distance between rows of $2.9 \mathrm{~m}$ and within rows of $0.9 \mathrm{~m}$. A guyot pruning type has been performed since the establishment of the vineyard. Two cultivars were grown: the white-skinned 'Olaszrizling' and the red-skinned 'Turán'. Cultivar (cv) 'Olaszrizling' is declared as suitable for botrytised wine making (Robinson et al. 2013) and cv 'Turán' can be used for a unique red botrytised wine (Robinson et al. 2013). In the vineyard, fungicides were used in all years form early April to mid-July (Table 1). All sprays were applied with a Lochmann RPS10/70 axial airblast sprayer (Lochmann Plantatech, Nalles, Italy) with a ceramic hollow cone at 0.5 to $1.5 \mathrm{MPa}$ with a volume of $10001 \mathrm{ha}^{-1}$. Sprays against insects were not applied in either years and a mechanical weed management was applied two to three times annually in the vineyard.

Rainfall $(\mathrm{mm})$ and daily temperature (mean, minimum and maximum; ${ }^{\circ} \mathrm{C}$ ) were detected using a Boreas agrometeorological station (Boreas Ltd., Érd, Hungary) in the vineyard from 1 September until 30 November in the 3 years.

Three sampling months (September, October and November) were chosen according to the 3-monthperiod of noble rot development. According to this, noble rot incidence was assessed in 12 September, 27 October and 28 November in each year. Grape clusters of 20 plants were assessed on each cultivar in each sampling date. A grape bunch was considered to be noble rotted if at least one berry showed the typical symptoms caused by $B$. cinerea. Noble rot incidence was calculated for each observed plant. Grape berries with symptoms of noble rot were collected from the vineyard at the same dates in each year. A minimum of 20 samples of naturally-botrytised grape berries was collected in each month-year combination and on each cultivar. Then $B$. cinerea from the samples were cultured on rose bengal chloramphenicol (RBC) medium
(Scharlab S.L., Spain). Then single-spore cultures were selected and maintained on potato dextrose agar (PDA) (Biolab Zrt, Budapest, Hungary). For growth tests, a 5$\mathrm{mm}$ mycelial plug was cut from the margin of an actively growing 4-day-old culture and placed in the center of a Petri dish containing PDA. Plates were incubated at $20{ }^{\circ} \mathrm{C}$ (optimum temperature) and at 15 and $25^{\circ} \mathrm{C}$ (sub-optimum temperatures) in dark. Mycelial growth diameter was measured to a 4-day post inoculation. Three replicates were performed for each isolate and the experiment was carried out twice.

Morphological features of the same 20 isolates were determined for the 3 years, three sampled months and the two cultivars in order to investigate their effects on the morphological types of $B$. cinerea isolates. Morphological types were characterized after a 21-days inoculation but only on those isolates that were grown at the optimum temperature $\left(20^{\circ} \mathrm{C}\right)$. Then cultures were macroscopically examined for sporulation, mycelium and sclerotium production (Table 3 ). Then isolates were classified into the morphological groups of mycelial (M) or sclerotial (S) types, which contained four mycelial (M I, M II, M III, M IV) and four sclerotial (S I, S II, S III, S IV) types according to Martinez et al. (2003) (Table 2). Three replicates were performed for each isolate and the experiment was carried out twice.

Data on noble rot incidence were analysed by using analyses of variance (ANOVA) in order to determine the effect of year, sampling month, cultivar, and their interactions. Data on mycelial growth rate were also analysed by using ANOVA in order to determine the effect of year, sampling month, cultivar, temperature and their interactions. For both measures, means were separated by using an LSD test $(\alpha=0.05)$.

Frequency distribution (FD\%) of each morphological type was calculated for each year, sampling month and cultivar as $\mathrm{FD} \%=$ (isolate numbers in a given classes of morphological type / total numbers of isolates) $\times 100$. Frequency distributions were then analysed by using ANOVA in order to determine the effect of year, sampling month, cultivar, morphological group and their interactions. Means were separated by using an LSD test $(\alpha=0.05)$. Before the analyses, frequency distributions were arcsine-square root transformed for data normality.

Pearson correlation between morphological types $\left(\sum\right.$ S-type and $\sum$ M-type) and monthly noble rot incidences (September, October and November) was calculated for the combined data set of the 3 years and two cultivars. 
Table 1 Fungicide spray schedules from early April to mid-July in the experimental vineyard (2013-2015, Somolya, Hungary ${ }^{\mathrm{a}}$

\begin{tabular}{|c|c|c|c|}
\hline Date & Active ingredients & Trade name $\mathrm{e}^{\mathrm{b}}$ & Dosage $(\%)$ \\
\hline \multicolumn{4}{|l|}{2013} \\
\hline 10 April & copper hydroxide, $24 \%$; plant oil, $25 \%$ & Vegesol RS & 0.4 \\
\hline \multirow[t]{2}{*}{ 1, 10 May } & elemental sulphur, $80 \%$ & Kumulus S & 0.4 \\
\hline & mancozeb, $750 \mathrm{~g} \mathrm{~kg}^{-1}$ & Vondozeb DG & 0.2 \\
\hline \multirow[t]{2}{*}{24 May, 11 June } & elemental sulphur, $80 \%$ & Kumulus S & 0.4 \\
\hline & dimetomorf, $9 \%$; mancozeb, $60 \%$ & Acrobat MZ WG & 0.2 \\
\hline \multirow[t]{2}{*}{25 June, 5 July } & elemental sulphur, $80 \%$ & Kumulus S & 0.4 \\
\hline & copper hydroxide, $77 \%$ & Champion WG & 0.2 \\
\hline 15 July & elemental sulphur, $80 \%$ & Kumulus S & 0.4 \\
\hline \multicolumn{4}{|l|}{2014} \\
\hline 12 April & copper hydroxide, $24 \%$; plant oil, $25 \%$ & Vegesol RS & 0.4 \\
\hline \multirow[t]{2}{*}{ 5, 16 May } & elemental sulphur, $80 \%$ & Kumulus S & 0.4 \\
\hline & mancozeb, $750 \mathrm{~g} \mathrm{~kg}^{-1}$ & Vondozeb DG & 0.2 \\
\hline \multirow[t]{2}{*}{25 May, 13 June } & elemental sulphur, $80 \%$ & Kumulus S & 0.4 \\
\hline & dimetomorf, $9 \%$; mancozeb, $60 \%$ & Acrobat MZ WG & 0.4 \\
\hline \multirow[t]{2}{*}{24 June, 5 July } & elemental sulphur, $80 \%$ & Kumulus S & 0.4 \\
\hline & copper hydroxide, $77 \%$ & Champion WG & 0.2 \\
\hline 10 July & elemental sulphur, $80 \%$ & Kumulus S & 0.4 \\
\hline \multirow[t]{2}{*}{15 July } & elemental sulphur, $80 \%$ & Kumulus S & 0.4 \\
\hline & meptildinokap, $350 \mathrm{~g} \mathrm{l}^{-1}$ & Karathane Star & 0.075 \\
\hline 20 July & meptildinokap, $350 \mathrm{~g} \mathrm{l}^{-1}$ & Karathane Star & 0.075 \\
\hline \multicolumn{4}{|l|}{2015} \\
\hline 10 April & copper hydroxide, $24 \%$; plant oil, $25 \%$ & Vegesol RS & 0.4 \\
\hline \multirow[t]{2}{*}{ 2, 12 May } & elemental sulphur, $80 \%$ & Kumulus S & 0.4 \\
\hline & mancozeb, $750 \mathrm{~g} \mathrm{~kg}^{-1}$ & Vondozeb DG & 0.2 \\
\hline \multirow[t]{2}{*}{22 May, 9 June } & elemental sulphur, $80 \%$ & Kumulus S & 0.4 \\
\hline & dimetomorf, $9 \%$; mancozeb, $60 \%$ & Acrobat MZ WG & 0.2 \\
\hline \multirow[t]{2}{*}{23 June, 4 July } & elemental sulphur, $80 \%$ & Kumulus S & 0.4 \\
\hline & copper hydroxide, $77 \%$ & Champion WG & 0.2 \\
\hline 15 July & elemental sulphur, $80 \%$ & Kumulus S & 0.4 \\
\hline
\end{tabular}

${ }^{\text {a }}$ Sprays against insects were not applied in either years and a mechanical weed management was applied two to three times annually in the vineyard

${ }^{\mathrm{b}}$ Vegesol RS (BVN Ltd, Budapest Hungary), Kumulus S (BASF Hungary Ltd., Budapest, Hungary), Acrobat MZ WG (BASF Hungary Ltd., Budapest, Hungary), Vondozeb DG (UPL Europe Ltd., Cheshire, UK), Champion WG (Kwizda Agro Ltd, Budapest, Hungary), Karathane Star (Dow AgroSciences Hungary Ltd, Budapest, Hungary)

All analyses were done using Genstat 5 Release 4.1 (Lawes Agricultural Trust, IACR, Rothamsted, UK).

The September daily temperatures were the highest in 2015, the October ones in 2013, while the November ones in 2014 (Table 3). During the three autumn months, the maximum values of daily temperature were 22.7 , 23.1 , and $24.0^{\circ} \mathrm{C}$ in 2013,2014 , and 2015 , respectively. The total amount of rainfall was the lowest $(112.5 \mathrm{~mm})$ in the autumn of 2013 and the highest (199.4 mm) in the autumn of 2015 (Table 3). Weather conditions for noble rot development were more favourable in the autumn of 2013 compared to either the autumn of 2014 or 2015.

Analyses of variance indicated significant differences among years, months, and cultivars (mean square = 874.4, 14,201.2, and 2035.4; $P<0.001,<0.001$, and $<0.001$, respectively) for noble rot incidence. In addition, all interactions among treatment factors were nonsignificant. Across the 3 years and two cultivars, noble 
Table 2 Morphological types of Botrytis cinerea isolates grown on PDA medium at $20{ }^{\circ} \mathrm{C}$ according to Martinez et al. (2003)

\begin{tabular}{|c|c|c|c|c|c|c|c|c|}
\hline \multirow{2}{*}{$\begin{array}{c}\text { Morphological } \\
\text { type }\end{array}$} & \multicolumn{4}{|c|}{ Mycelial type 'M' } & \multicolumn{4}{|c|}{ Sclerotial type 'S' } \\
\hline & M I & M II & M III & M IV & S I & S II & S III & S IV \\
\hline Mycelium & Short & Aerial & $\begin{array}{c}\text { Mycelial } \\
\text { masses }\end{array}$ & Aerial & Rather short & Rather short & Rather short & Rather short \\
\hline Sporulation $^{\mathrm{a}}$ & - & \pm & - & \pm & \pm & \pm & - & - \\
\hline Sclerotia ${ }^{b}$ & - & 0 & - & - & $\begin{array}{l}\text { large and } \\
\text { small } \\
\text { irregularly }\end{array}$ & in circle & $\begin{array}{l}\text { large, placed } \\
\text { irregularly }\end{array}$ & $\begin{array}{c}\text { numerous, } \\
\text { scattered }\end{array}$ \\
\hline $\begin{array}{l}\text { Representative } \\
\text { image }\end{array}$ & & & & & & & & \\
\hline
\end{tabular}

${ }^{\mathrm{a}}$ Sporulation: $-=$ very rare sporulation, $\pm=$ sporulates eventually

${ }^{\mathrm{b}}$ Sclerotia: $0=$ absence of sclerotia, $-=$ very rare sclerotia

rot incidence ranged from 0.5 to $10.3 \%$, from 4.3 to $39.4 \%$, and from 26.5 to $78.7 \%$ for the sampling months of September, October, and November, respectively (Table 4). The highest noble rot incidence (78.7\%) was assessed on cv. 'Turán' in November 2015 while the lowest one $(0.5 \%)$ on cv. 'Olaszrizling' in September 2013. Noble rot incidences were significantly higher on cv. 'Turán' compared to cv. 'Olaszrizling' in November in all years. Noble rot incidences were significantly

Table 3 Daily temperatures (mean, minimum and maximum) and rainfall in September, October and November in the experimental vineyard (2013-2015, Somolya, Hungary)

\begin{tabular}{lll}
\hline Year and Month & Daily temperature $\left({ }^{\circ} \mathrm{C}\right)$ & Rainfall $(\mathrm{mm})$ \\
\cline { 2 - 3 } & Mean Minimum Maximum
\end{tabular}

2013

\begin{tabular}{|c|c|c|c|c|}
\hline September & 15.4 & 5.8 & 28.0 & 27.4 \\
\hline October & 13.3 & 0.6 & 24.6 & 40.5 \\
\hline November & 8.1 & -4.0 & 15.5 & 44.6 \\
\hline Overall autumn $^{\mathrm{a}}$ & 12.3 & 0.8 & 22.7 & 112.5 \\
\hline \multicolumn{5}{|l|}{2014} \\
\hline September & 17.9 & 6.8 & 28.4 & 91.8 \\
\hline October & 12.5 & 2.6 & 23.7 & 50.0 \\
\hline November & 7.8 & -1.9 & 17.2 & 11.6 \\
\hline Overall autumn & 12.7 & 2.5 & 23.1 & 153.4 \\
\hline \multicolumn{5}{|l|}{2015} \\
\hline September & 18.7 & 9.2 & 34.8 & 54.8 \\
\hline October & 11.1 & 3.2 & 23.3 & 122.0 \\
\hline November & 7.2 & -2.2 & 13.8 & 22.6 \\
\hline Overall autumn & 12.3 & 3.4 & 24.0 & 199.4 \\
\hline
\end{tabular}

${ }^{a}$ Average values of the three autumn months for each dialy temperature parameter (mean, minimum and maximum) and sum of rainfall in the three autumn months lower in September compared to values in November in all the 3 years (Table 4).

Analyses of variance indicated significant differences among years, months, and temperatures (mean square $=$ 13,192.4, 4448.9, and 236.5; $P<0.001,=0.037$, and $<0.001$, respectively) for mycelial growth rate but the

Table 4 Noble rot incidence (\%) caused by Botrytis cinera on grape cluster of cultivars 'Turán' and 'Olaszrizling' in September, October and November in the experimental vineyard (2013-2015, Somolya, Hungary)

\begin{tabular}{|c|c|c|c|c|}
\hline \multirow[t]{2}{*}{ Year and Month } & \multicolumn{2}{|l|}{ Cultivar } & \multirow[t]{2}{*}{$\mathrm{LSD}_{0.05}{ }^{\mathrm{a}}$} & \multirow[t]{2}{*}{ Overall } \\
\hline & ‘Turán’ & 'Olaszrizling' & & \\
\hline \multicolumn{5}{|l|}{2013} \\
\hline September & $5.1 \mathrm{aA}^{\mathrm{b}}$ & $0.5 \mathrm{aB}$ & 3.7 & $2.6 \mathrm{a}$ \\
\hline October & $7.1 \mathrm{a}$ & $4.3 \mathrm{a}$ & $\mathrm{ns}^{\mathrm{c}}$ & $5.7 \mathrm{a}$ \\
\hline November & $50.6 \mathrm{bA}$ & $28.4 \mathrm{bB}$ & 7.6 & $39.5 \mathrm{~b}$ \\
\hline $\mathrm{LSD}_{0.05}$ & 7.0 & 4.2 & & 5.6 \\
\hline \multicolumn{5}{|l|}{2014} \\
\hline September & $10.3 \mathrm{a}$ & $7.2 \mathrm{a}$ & ns & $8.8 \mathrm{a}$ \\
\hline October & $39.4 \mathrm{bA}$ & $24.3 \mathrm{bB}$ & 6.9 & $31.9 \mathrm{~b}$ \\
\hline November & $37.6 \mathrm{bA}$ & $26.5 \mathrm{bB}$ & 6.6 & $32.1 \mathrm{~b}$ \\
\hline $\mathrm{LSD}_{0.05}$ & 6.9 & 5.8 & & 6.7 \\
\hline \multicolumn{5}{|l|}{2015} \\
\hline September & $4.2 \mathrm{a}$ & $0.8 \mathrm{a}$ & ns & $2.5 \mathrm{a}$ \\
\hline October & $9.7 \mathrm{a}$ & $7.3 \mathrm{a}$ & ns & $8.5 \mathrm{a}$ \\
\hline November & $78.7 \mathrm{bA}$ & $57.6 \mathrm{bB}$ & 8.9 & $68.2 \mathrm{~b}$ \\
\hline $\mathrm{LSD}_{0.05}$ & 11.5 & 7.4 & & 9.5 \\
\hline
\end{tabular}

${ }^{\mathrm{a}} \mathrm{LSD}_{0.05}=$ Least Significant Difference at $P=0.05$

${ }^{\mathrm{b}}$ For each column, different small letters indicate significant differences at $P=0.05$ among years, months. For each row, different capital letters indicate significant differences at $P=0.05$ among cultivars within a given month

${ }^{\mathrm{c}} \mathrm{ns}=$ non-significant 
differences among cultivars were non-significant (mean square $=138.7, P=0.164$ ). In addition, all interactions among treatment factors were non-significant. As cultivar being non-significant, data of mycelial growth rate were averaged for the two cultivars and not shown separately for temperatures, years and months (Table 5). Across the 3 years and the three sampling months, mycelial growth rate ranged from 59 to $79 \mathrm{~mm}$, from 75 to $84 \mathrm{~mm}$, and from 55 to $77 \mathrm{~mm}$ for incubation temperatures of 15,20 , and $25^{\circ} \mathrm{C}$, respectively (Table 5). The highest mycelial growth rate $(84 \mathrm{~mm})$ was measured for the incubation temperature of $20{ }^{\circ} \mathrm{C}$ on isolates collected in September 2014 while the lowest one $(55 \mathrm{~mm})$ for the incubation temperature of $25^{\circ} \mathrm{C}$ on isolates collected in September 2014. Mycelial growth rates at 15 and $25^{\circ} \mathrm{C}$ were higher in 2013 compared to 2014 and 2015 ; however, the growth rates at $20^{\circ} \mathrm{C}$ were higher in 2014 compared to 2013 and 2015 (Table 5).

Table 5 Mycelial growth rate (mm) of Botriytis cinerea after 4 days incubation at 15, 20, and $25^{\circ} \mathrm{C}$ in 3 years (2013, 2014, and 2015) during 3 months (September, October, and November) of noble rot development (Somolya, Hungary)

\begin{tabular}{|c|c|c|c|c|c|}
\hline \multirow[t]{2}{*}{ Year, Month } & \multicolumn{3}{|c|}{ Temperature range } & \multirow[t]{2}{*}{$\operatorname{LSD}_{0.05}{ }^{\mathrm{a}}$} & \multirow[t]{2}{*}{ Overall Temp ${ }^{b}$} \\
\hline & $15^{\circ} \mathrm{C}$ & $20^{\circ} \mathrm{C}$ & $25^{\circ} \mathrm{C}$ & & \\
\hline \multicolumn{6}{|l|}{2013} \\
\hline September & $79 \mathrm{bB}^{\mathrm{c}}$ & $79 \mathrm{~B}$ & $74 \mathrm{~A}$ & 3.6 & 77 \\
\hline October & $76 \mathrm{ab}$ & 76 & 74 & $\mathrm{~ns}^{\mathrm{d}}$ & 76 \\
\hline November & $75 \mathrm{a}$ & 77 & 77 & ns & 76 \\
\hline $\mathrm{LSD}_{0.05}$ & 3.4 & $\mathrm{~ns}$ & $\mathrm{~ns}$ & & ns \\
\hline \multicolumn{6}{|l|}{2014} \\
\hline September & $59 \mathrm{~A}$ & $84 \mathrm{bB}$ & $55 \mathrm{~A}$ & 7.5 & 66 \\
\hline October & $59 \mathrm{~A}$ & $83 \mathrm{bB}$ & $56 \mathrm{~A}$ & 7.4 & 66 \\
\hline November & $61 \mathrm{~A}$ & $75 \mathrm{aB}$ & $56 \mathrm{~A}$ & 6.8 & 64 \\
\hline $\mathrm{LSD}_{0.05}$ & $\mathrm{~ns}$ & 3.6 & ns & & ns \\
\hline \multicolumn{6}{|l|}{2015} \\
\hline September & $61 \mathrm{~A}$ & $75 \mathrm{~B}$ & $67 \mathrm{aA}$ & 6.9 & 68 \\
\hline October & $62 \mathrm{~A}$ & $76 \mathrm{~B}$ & $71 \mathrm{abB}$ & 7.0 & 69 \\
\hline November & $61 \mathrm{~A}$ & $75 \mathrm{~B}$ & $72 \mathrm{bB}$ & 7.3 & 69 \\
\hline $\mathrm{LSD}_{0.05}$ & $\mathrm{~ns}$ & ns & 4.2 & & ns \\
\hline \multicolumn{6}{|l|}{ Overall month } \\
\hline September & $66 \mathrm{~A}$ & $79 \mathrm{~B}$ & $65 \mathrm{~A}$ & 6.5 & 70 \\
\hline October & $66 \mathrm{~A}$ & $78 \mathrm{~B}$ & $67 \mathrm{~A}$ & 7.4 & 71 \\
\hline November & $65 \mathrm{~A}$ & $76 \mathrm{~B}$ & $68 \mathrm{~A}$ & 7.1 & 70 \\
\hline $\mathrm{LSD}_{0.05}$ & ns & $\mathrm{ns}$ & $\mathrm{ns}$ & & ns \\
\hline \multicolumn{6}{|l|}{ Overall year } \\
\hline 2013 & $77 \mathrm{~b}$ & $77 \mathrm{ab}$ & $75 \mathrm{~b}$ & ns & $76 \mathrm{~b}$ \\
\hline 2014 & $60 \mathrm{aA}$ & $81 \mathrm{bB}$ & $56 \mathrm{aA}$ & 7.9 & $65 \mathrm{a}$ \\
\hline 2015 & $61 \mathrm{aA}$ & $75 \mathrm{aB}$ & $70 \mathrm{bB}$ & 7.6 & $69 \mathrm{a}$ \\
\hline $\mathrm{LSD}_{0.05}$ & 6.6 & 5.8 & 7.3 & & 6.4 \\
\hline \multicolumn{6}{|l|}{ Overall } \\
\hline Year and Month & $66 \mathrm{~A}$ & $78 \mathrm{~B}$ & $67 \mathrm{~A}$ & 7.9 & 70 \\
\hline
\end{tabular}

${ }^{\mathrm{a}} \mathrm{LSD}_{0.05}=$ Least Significant Difference at $P=0.05$

${ }^{\mathrm{b}}$ Overall Temp $=$ overall temperature from the temperature ranges of 15,20 , and $25^{\circ} \mathrm{C}$

${ }^{\mathrm{c}}$ For each column, different small letters indicate significant differences at $P=0.05$ among years, months. For each row, different capital letters indicate significant differences at $P=0.05$ among temperature ranges

${ }^{\mathrm{d}}$ ns $=$ non-significant 
The overall mean growth rate was the highest in 2013 (76 mm) compared to either 2014 or 2015 (65 or $69 \mathrm{~mm}$, respectively). Mycelial growth rates were significantly different between earlier (September) and later (November) sampling months in three cases i) in 2013 at $15^{\circ} \mathrm{C}$, ii) in 2014 at $20^{\circ} \mathrm{C}$, and iii) in 2015 at $25{ }^{\circ} \mathrm{C}$ (Table 5).

Analyses of variance indicated significant differences among years, months, and morphological groups (mean square $=1095.7,998.6$, and 5652.9; $P=0.005,=0.006$, and $<0.001$, respectively) for the frequency distribution of the morphological types but the differences among cultivars were non-significant (mean square $=127.6$, $P=0.438$ ). In addition, all interactions among treatment factors were non-significant. As cultivar being non-significant, data on the frequency distribution of the morphological types were averaged for the two cultivars and not shown separately for years, months, and morphological types (Table 6). Frequency distribution of the morphological group of mycelial types ( $\sum$ M-type, ranged from 51.4 to $91.7 \%$, mean $70.5 \%$ ) were significantly higher compared to the sclerotial types ( $\sum$ S-type, ranged from 8.3 to $48.6 \%$, mean $29.5 \%$ ) across the 3 years and the three sampling months (Table 6). In general, the most frequent mycelial and sclerotial types were M I-III and S IV (means were 21.5, 16.1, 28.9, and $13.1 \%$, respectively). The highest frequency distribution (58.3\%) was measured for M III type on isolates collected in September 2013. Isolates of mycelial types were more frequent in 2013 ( $\sum$ M-type 82.2\%) compared to 2015 ( $\sum$ M-type $\left.57.1 \%\right)$. The frequency distributions of morphological types among sampling months showed differences between the earlier (September or/ and October) and the later months (November) in 2013 for M I-III, S II and S IV types; in 2014 for M I, M III, M IV, S I, S III and S IV types; and in 2015 for M I, M IV and S I-IV types (Table 6).

Pearson correlation analyses revealed a significant positive relationship between morphological types $\left(\sum\right.$ S-type and $\sum \mathrm{M}$-type) and monthly noble rot incidences ( $r=0.676$ and $P=0.048$ ). The relationship indicated that the increasing noble rot incidence from September to November resulted in an increasing frequency of the morphological type $\mathrm{S}$ while the frequency of morphological type $\mathrm{M}$ decreased.

In this study, the thermic optimum was the same for mycelial growth of $B$. cinerea strains originated either from red- or white-skinned grape cultivars (non-significant cultivar effect in ANOVA). The greatest growth rate was observed at $20{ }^{\circ} \mathrm{C}$ while the growth rate decreased at 15 and $25{ }^{\circ} \mathrm{C}$ (Table 5). Our data confirmed most previously reported results, for instance, Martinez et al. (2003) and Ciliberti et al. (2015b) showed that strains of $B$. cinerea were similarly affected by temperature, and the greatest mycelial growth rate or infection was observed at $20^{\circ} \mathrm{C}$, while they decreased in the order at 25,15 , and $5{ }^{\circ} \mathrm{C}$. Other previous studies confirmed a same temperature effect on the infection of grape berries by B. cinerea (Nair and Allen 1993) and on the development of aerial mycelium of $B$. cinerea on grape berries (Thomas et al. 1988). Our results on temperature also confirmed the model developed for predicting the combined effect of temperature and the mycelial growth rate of B. cinerea (Judet-Correia et al. 2010) and the model describing the relationship between the incidence of berry infection and temperature (Broome et al. 1995). In addition, a mechanistic model of $B$. cinerea on grapevines including weather, vine growth stage, and the main infection pathways was developed by GonzálezDomínguez et al. (2015), which also supports the findings in this study. In connection with these infection pathways, the main four grape growth stages (end of flowering, pre-bunch closure, veraison and before harvest) can differ in the tissue susceptibility for the infection. The improved predicting model by GonzálezDomínguez et al. (2015) verified that the early season infection influenced the severity of Botrytis infection during berry ripening. This indicates that latent infection under favourable conditions could also be a driving factor in this Hungarian study for the noble rot development.

In relation to temperature effect on mycelial growth rate, the year influence on mycelial growth rate was analysed by Damialis et al. (2015). Authors confirmed a significant connection between mycelial growth rate of $B$. cinerea and average decadal air temperature from the 1980s to the 2000s. Their findings may support our results on the growth rate differences among years. In 2013 , the mean maximum daily temperature during the autumn $\left(22.7^{\circ} \mathrm{C}\right)$ was the closest to the optimum $\left(20{ }^{\circ} \mathrm{C}\right)$ for the greatest mycelial growth of the B. cinerea. Meanwhile in 2014 and 2015, the differences between the optimum temperature $\left(20^{\circ} \mathrm{C}\right)$ and the mean maximum daily temperatures during the autumn (23.1 and $24.0^{\circ} \mathrm{C}$, respectively) were higher than in 2013, which is in line with a lower mycelial growth rate and a lower overall frequency of M-types in the isolates of 2014 and 2015. 


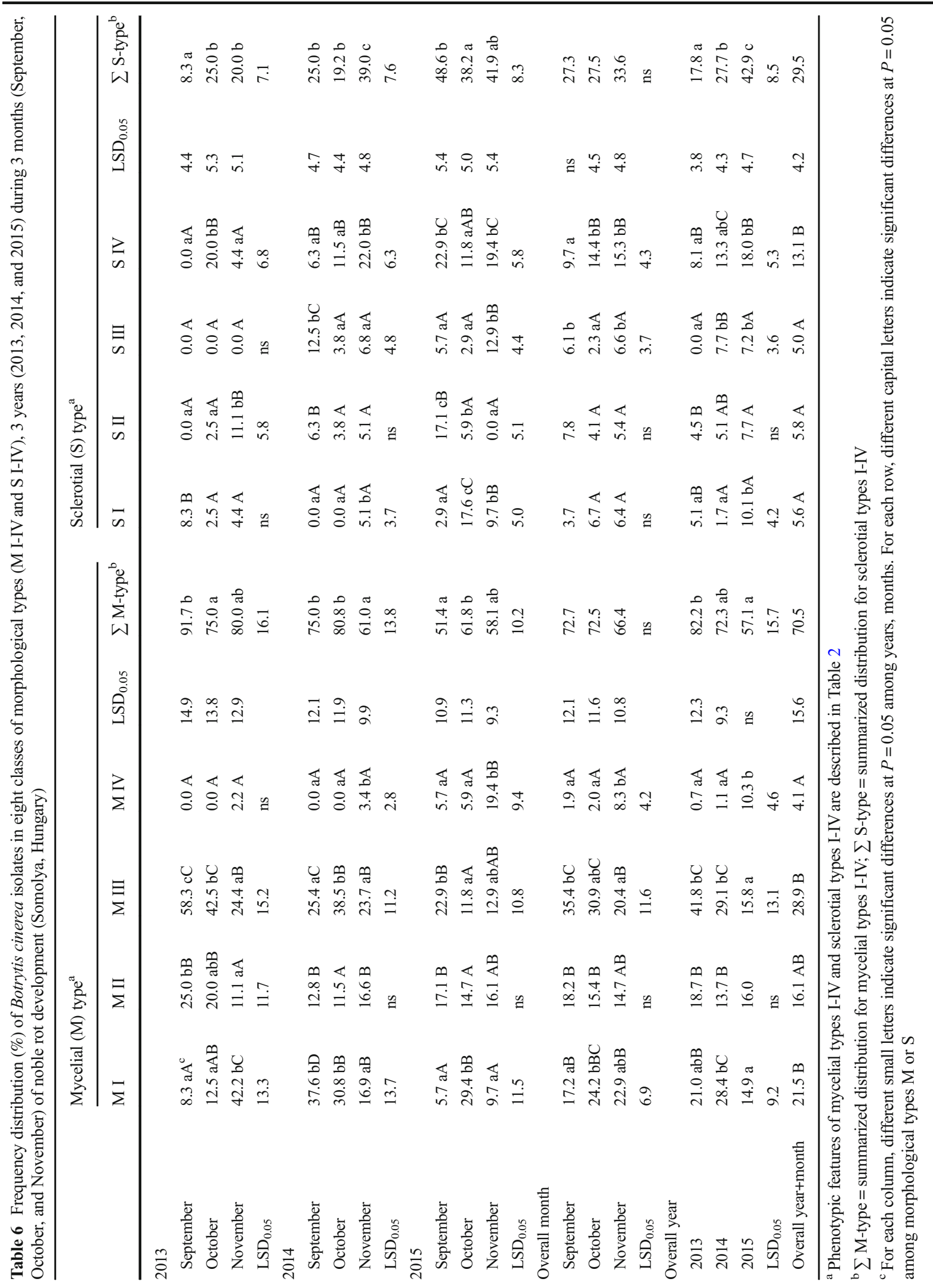


Previous studies showed that an increased concentration of phenolic compounds inhibited the growth of B. cinerea (Padgett and Morrison 1990; Pezet et al. 2003; Deytieux-Belleau et al. 2009; Köycü et al. 2014). In addition, the growth and latency of $B$. cinerea were inhibited more in the berries of darkskinned cultivars compared to white-skinned ones with lower concentration of phenolic compounds. In our study, although berries of dark-skinned cv 'Turán' contained more polyphenols (Balga et al. 2014) than the white-skinned cv 'Olaszrizling', differences in mycelial growth rate and morphological types of $B$. cinerea did not occurred between isolates originated from whiteand dark-skinned cultivars (non-significant cultivar effect in ANOVA). This result clearly indicated that the effect of dark-skinned cultivars on gray mold inhibition might occur in the plant tissues (such as in berries) but did not cause differences in the growth and morphological features of $B$. cinerea isolates in the laboratory originated either from dark- or white-skinned cultivars.

This study was the first confirming any effects of sampling months on mycelial growth and morphological types of $B$. cinerea during noble rot development (Tables 5 and 6) and their possible connection with noble rot incidence in the field. Magyar and Bene (2006) described the morphological features of $B$. cinerea in noble rotted berries under the specific weather conditions of the Tokaj wine district but these features were not connected further to sampling months. Our study showed that the effect of sampling months had stronger effects on the morphological types of $B$. cinerea isolates than on the mycelial growth rate of the isolates (Tables 5 and 6), which may influence the botrytisation process of berries in earlier and later months of the autumn.

In conclusion, our results showed possible effects of year/sampling month on noble rot incidence in connection with mycelial growth rate and morphological types of $B$. cinerea strains isolated during noble rot development. These differences may also appear in other European vineyards during the noble rot development of berries in autumn.

Acknowledgements Open access funding provided by University of Debrecen (DE). This work was supported by a GINOP2.3.2-15-2016-00061 project of Eszterházy Károly University.

\section{Compliance with ethical standards}

Conflict of interest The authors declare no conflict of interest.
Ethical approval This manuscript is original and not published elsewhere. The authors discussed the result, read and approved the final article. The authors confirm that there are no ethical issues in publication of the manuscript.

Research involving human participants and/or animals This study does not contain studies with human participants or animals performed by any of the authors.

Open Access This article is distributed under the terms of the Creative Commons Attribution 4.0 International License (http:// creativecommons.org/licenses/by/4.0/), which permits unrestricted use, distribution, and reproduction in any medium, provided you give appropriate credit to the original author(s) and the source, provide a link to the Creative Commons license, and indicate if changes were made.

\section{References}

Balga, I., Leskó, A., Ladányi, M., \& Kállay, M. (2014). Influence of ageing on changes in polyphenolic compounds in red wines. Czech Journal of Food Science, 32, 563-569.

Bene, Z., \& Magyar, I. (2004). Characterization of yeast and mould biota of botrytized grapes in Tokaj wine region in the years 2000 and 2001. Acta Alimentaria, 33(3), 259-267.

Blanco-Ulate, B., Amrine, K. C. H., Collins, T. S., Rivero, R. M., Vicente, A. R., Morales-Cruz, A., Doyle, C. L., Ye, Z., Allen, G., Heymann, H., Ebeler, S. E., \& Cantu, D. (2015). Developmental and metabolic plasticity of white-skinned grape berries in response to Botrytis cinerea during noble rot. Plant Physiology, 169, 2422-2443.

Broome, J. C., English, J. T., Marois, J. J., Latorre, B. A., \& Aviles, J. C. (1995). Development of an infection model for Botrytis bunch rot of grapes based on wetness duration and temperature. Phytopathology, 85, 97-102.

Campia, P., Venturini, G., Moreno-Sanz, P., Casati, P., \& Toffolatti, S. L. (2016). Genetic structure and fungicide sensitivity of Botrytis cinerea populations isolated from grapevine in northern Italy. Plant Pathology, 66(6), 890-899.

Cantoral, J. M., Collado, I. G., González, R., Cantoral, J. M., \& Collado, I. G. (2011). Filamentous fungi (Botrytis cinerea). Pp. 257-277. In R. González Garcia, R. Munoz, \& A. V. Carrascosa (Eds.), Molecular wine microbiology. Amsterdam: Elsevier.

Ciliberti, N., Fermaud, M., Languasco, L., \& Rossi, V. (2015a). Influence of fungal strain, temperature, and wetness duration on infection of grapevine inflorescences and young berry clusters by Botrytis cinerea. Phytopathology, 105(3), 325333.

Ciliberti, N., Fermaud, M., Roudet, J., \& Rossi, V. (2015b). Environmental conditions affect Botrytis cinerea infection of mature grape berries more than the strain or transposon genotype. Phytopathology, 105, 1090-1096.

Damialis, A., Mohammad, A. B., Halley, J. M., \& Gange, A. C. (2015). Fungi in a changing world: Growth rates will be elevated, but spore production may decrease in future 
climates. International Journal of Biometeorology, 59(9), $1157-1167$.

Deytieux-Belleau, C., Geny, L., Roudet, J., Mayet, V., Donèche, M., \& Fermaud, M. (2009). Grape berry skin features related to ontogenic resistance to Botrytis cinerea. European Journal of Plant Pathology, 125, 551-563.

Elad, Y., Vivier, M., \& Fillinger, S. (2016). Botrytis the good, the bad and the ugly. In Y. Elad \& S. Fillinger (Eds.), Botrytis The fungus, the pathogen and its management in agricultural systems (pp. 1-15). Cham: Springer.

Fournier, E., Gladieux, P., \& Giraud, T. (2013). The 'Dr Jekyll and Mr Hyde fungus': Noble rot versus gray mold symptoms of Botrytis cinerea on grapes. Evolutionary Applications, 6(6), 960-969.

González-Domínguez, E., Caffi, T., Ciliberti, N., \& Rossi, V. (2015). A mechanistic model of Botrytis cinerea on grapevines that includes weather, vine growth stage, and the main infection pathways. PLoS One, 10(10), e0140444.

González-Domínguez, E., Fedele, G., Caffi, T., Delière, L., Sauris, P., Gramaje, D., Ramos-Saez de Ojer, J. L., Díaz-Losada, E., Díez-Navajas, A. M., Bengoa, P., \& Rossi, V. (2019). A network meta-analysis provides new insight into fungicide scheduling for the control of Botrytis cinerea in vineyards. Pest Management Science, 75(2), 324-332.

Holtz, G., Coertze, S., \& Williamson, B. (2007). The ecology of Botrytis on plant surfaces. In Y. Elad, B. Williamson, P. Tudzynski, \& N. Delen (Eds.), Botrytis: Biology, pathology and control (pp. 9-27). Dordrecht: Springer.

Judet-Correia, D., Bollaert, S., Duquenne, A., Charpentier, C., Bensoussan, M., \& Dantigny, P. (2010). Validation of a predictive model for the growth of Botrytis cinerea and Penicillium expansum on grape berries. International Journal of Food Microbiology, 142(1), 106-113.

Köycü, N., Özer, N., Martignoni, D., Aleandri, M., Timperio, A., Magro, P., \& Chilosi, G. (2014). T-resveratrol accumulation and polygalacturonase inhibition during infection of grape berries by Botrytis cinerea. Journal of Plant Pathology, 96(2), 261-269.

Lorenzini, M., \& Zapparoli, G. (2014). An isolate morphologically and phylogenetically distinct from Botrytis cinerea obtained from withered grapes possibly represents a new species of Botrytis. Plant Pathology, 63(6), 1326-1335.

Magyar, I. (2011). Botrytized wines. Advances in Food and Nutrition Research, 63, 147-206.

Magyar, I., \& Bene, Z. (2006). Morphological and taxonomic study on mycobiota of noble rotted grapes in the Tokaj wine district. Acta Alimentaria, 35(2), 237-246.

Martinez, F., Blancard, D., Lecomte, P., Levis, C., Dubos, B., \& Fermaud, M. (2003). Phenotypic differences between vacuma and transposa subpopulations of Botrytis cinerea. European Journal of Plant Pathology, 109(5), 479-488.
Martinez, F., Dubos, B., \& Fermaud, M. (2005). The role of saprotrophy and virulence in the population dynamics of Botrytis cinerea in vineyards. Phytopathology, 95(6), 692700.

Nair, N. G., \& Allen, R. N. (1993). Infection of grape flowers and berries by Botrytis cinerea as a function of time and temperature. Mycological Research, 97, 1012-1014.

Padgett, M., \& Morrison, J. C. (1990). Changes in grape berry exudates during fruit development and their effect on mycelial growth of Botrytis cinerea. Journal of the American Society for Horticultural Science, 115(2), 269-273.

Pezet, R., Viret, O., Perret, C., \& Tabacchi, R. (2003). Latency of Botrytis cinerea Pers.: Fr. And biochemical studies during growth and ripening of two grape berry cultivars, respectively susceptible and resistant to grey mould. Journal of Phytopathology, 151, 208-214.

Ribéreau-Gayon, P., Dubourdieu, D., Donèche, B., \& Lonvaud, A. (2006). Handbook of enology: The microbiology of wine and vinifications. Vol 1 (2nd ed.). Chicester: John Wiley \& Sons.

Robinson, J., Harding, J., \& Vouillamoz, J. (2013). Wine grapes: A complete guide to 1,368 vine varieties, including their origins and Flavours. London: Penguin Book Ltd.

Rousseau, S., \& Doneche, B. (2001). Effects of water activity (aw) on the growth of some epiphytic micro-organisms isolated from grape berry. Vitis, 40(2), 75-78.

Thomas, C. S., Marois, J. J., \& English, J. T. (1988). The effects of wind speed, temperature, and relative humidity on development of aerial mycelium and conidia of Botrytis cinerea on grape. Phytopathology, 78, 260-265.

Váczy, K. Z., Sándor, E., Karaffa, L., Fekete, E., Árnyasi, M., Czeglédi, L., Kövics, G. J., Druzhinina, I. S., \& Kubicek, C. P. (2008). Sexual recombination in the Botrytis cinerea populations in Hungarian vineyards. Phytopathology, 98, 13121319.

Vallejo, I., Carbu, M., Rebordinos, L., \& Cantoral, J. (2003). Virulence of Botrytis cinerea strains on two grapevine varieties in South-Western Spain. Biologia - Section Cellular and Molecular Biology, 58(6), 1067-1074.

Walker, A. S., Gladieux, P., Decognet, V., Fermaud, M., Confais, J., Roudet, J., Bardin, M., Bout, A., Nicot, P. C., Poncet, C., \& Fournier, E. (2015). Population structure and temporal maintenance of the multihost fungal pathogen Botrytis cinerea: Causes and implications for disease management. Environmental Microbiology, 17(4), 1261-1274.

Williamson, B., Tudzynski, B., Tudzynski, P., \& van Kan, J. A. (2007). Botrytis cinerea: The cause of grey mould disease. Molecular Plant Pathology, 8(5), 561-580.

Youssef, K., \& Roberto, S. R. (2014). Salt strategies to control Botrytis mold of 'Benitaka' table grapes and to maintain fruit quality during storage. Postharvest Biology and Technology, 95, 95-102. 